\section{Scientist at the helm}

SIR - I would like to clarify some points concerning the recent reorganization at the Competitive Research Grants Office (CRGO) of the US Department of Agriculture (Nature 12 May, p.104). I am serving as programme manager for a CRGO programme and have had contacts with the USDA of ficials mentioned in your article. Although it was not clearly identified, the director's position referred to in the article is for the administrator of a newly created Office of Grants and Program Systems (OGPS), of which CRGO is a part, and therefore is not equivalent to the position of chief of CRGO. I have been assured by Assistant Secretary of Agriculture, Orville Bentley, Deputy Assistant Secretary E.L. Kendrick, and Acting Director of OGPS, Clarence Grogan that an active scientist will be appointed as chief to provide the scientific leadership in CRGO. This chief scientist will be recruited from the academic research community, in much the same manner as the past chiefs of CRGO.

I feel that your article was not entirely accurate in describing the present situation at CRGO and that it served only to create a negative image of CRGO. My impression is that Dr Bentley and his staff are committed to the cause of CRGO and I would urge members of the scientific community to give their support to that effort.

ROBERT B. GOLDBERC

Department of Biology,

University of California, Los Angeles, USA

\section{Soviet exchanges}

SIR - Your article of 12 May (p.106) referred to Academician Skryabin's planned discussion with the Royal Society. He did indeed come to see me and we briefly reviewed the operation of the exchange agreement between the Soviet Academy of Sciences and the Royal Society. Your article referred to "political" influences that had two years ago reduced the quota (measured in manmonths per year). In fact the quota of 49 man-months in each direction has remained unchanged since the present agreement was signed in 1977. The use of the exchange quota within our agreement over the past three years (April to March) has been as follows:

Man-months (no. of visits in brackets) 1980-81 1981-82 1982-83

$\begin{array}{lccc}\text { From Soviet Union } & 18 & 44 & 291 / 2 \\ & (14) & (24) & (18) \\ \text { From UK } & 161 / 2 & 193 / 4 & 223 / 4 \\ & (13) & (22) & (22)\end{array}$

Thus although the quota has not changed, it has been under-used in each of the past three years.

R.W.J. KEAY (Executive Secretary)

The Royal Society, London SWI, UK

\section{Data banking}

SIR - In response to your news article "Who's banker?"' (Nature 7 April, p.469), I would like to clarify some statements made about the National Biomedical Research Foundation (of which I am president) and its protein and nucleic acid sequence databases. The protein sequence collection has been funded for many years by the National Institutes of Health and that continuing funding will support preparation of the manuscript for Volume 6 of the Atlas of Protein Sequence and Structure. Although the tragic and sudden death in February of Dr Margaret Dayhoff is a great loss to us and to the scientific community, the staff that she trained are extremely competent to continue all aspects of the project, some having had over 14 years experience with us. We intend that the work that Dr Dayhoff inspired and led will continue and expand in the future.

The NBRF nucleic acid sequence database will continue as a special purpose collection in that we only include those sequences that code for proteins. We will continue to make our collection available to subscribers.

Neither the Los Alamos group nor Bolt, Beranek and Newman are primarily interested in proteins and, consequently, the format of the GenBank data is such that computer extraction and translation of the coding regions for proteins are very difficult. Furthermore, we find that GenBank annotations are inconsistent and that coding region sequences have not been verified to ensure that the proteins will translate correctly. The format of our Nucleic Acid Sequence Database makes extraction of protein sequences extremely convenient. All of the protein coding regions are translated and compared with the experimentally determined protein sequences (if known) and with the authors' translations. Thus, our data for protein coding regions are triple checked. Researchers primarily interested in protein coding regions will find that our Nucleic Acid Sequence Database is the most accurate available.

R.S. LEDII:Y (President)

National Biomedical Research

Foundation,

Washington DC, USA

\section{Culture collectors}

Sir - The paper by Hughes and Datta, "Conjugative plasmids in bacteria of the 'pre-antibiotic' era"' (Nature 21 April, p.725) is a good example of the usefulness of public depositories or national culture collections.

Too often collections such as Murray's are lost on the retirement or death of the collector when funds or space are not available to preserve the material.

In order to bc useful such collections need to have good documentation and adequate preservation technique. If the Murray collection had been freeze-dried the survival would probably have been 98 per cent instead of the 70 per cent reported.

On documentation, scientists at Fort Detrick recently found that a heat-sensitive plasmid was responsible for the toxigenic properties of the anthrax bacillus. In subsequent examination of a large number of collection strains only one was found that was devoid of the plasmid. This strain we believe came from Pasteur's laboratory via the Kral collection in Prague to the US Department of Agriculture. It would be nice to be able to say this was Pasteur's vaccination strain produced by "pasteurization" of the anthrax culture but we cannot since the provenance is too sketchy to be sure.

To assist in preserving such scientific heritage, the World Federation of Culture Collections has established a standing committee on preservation of endangered collections. Its chairman is Professor Rita Colwell, Department of Microbiology, University of Maryland, College Park, Maryland 20752, USA.

Any scientist knowing of imminent threats to the existence of well documented collections is urged to communicate with the committee so that timely rescue efforts can be undertaken. Also any scientists developing collections are urged to join the World Federation for Culture Collections in order to share and exchange information and cultures with this worldwide network. A revised directory of the world's culture collections has recently been published and is available from Thomas Roswall, Secretary, UNEP/UNESCO/ICRO Panel on Microbiology, Swedish University of Agricultural Sciences, S-750 07 Uppsala, Sweden.

ROBERT E. STEVENSON American Type Culture Collection, Rockville, Maryland, USA

\section{Conscious decision}

SIR - I have a comment on John Crook's suggestion in Nature of 5 May $^{1}$ that in the future some "gadgetry" may be discovered in the human brain which can be associated with consciousness. In my opinion such "gadgetry" has already been found. H.L.Seldon has reported ${ }^{2}$ that the axons in the human auditory cortex often travel in helically-wound bundles. If this is the case in other parts of the human cortex as well, it may be that consciousness is due to quantum mechanical resonance. The modes of consciousness may reflect quantization of angular momentum of total spike energy in such bundles.

Sycamore, Illinois, USA

NEIL BURTNESS

1. Crook, 3.H. Nature 303, 11 (1983)

2. Seldon, H.L.. Brain Res, 229, 295 (1981). 